Persia (Bull. Sch. Oriental Studies, 6, 103-131; 1930), records two earthquakes in Mazanderan, in 1802 and 1820, that have hitherto escaped the attention of seismologists. By the earlier shock, 70 towns and villages were destroyed, while the towns of Semnan and Damghan, to the south of the province, were seriously damaged.

\section{Rockefeller Medical Fellowships}

THE Rockefeller Medical Fellowships for the academic year 1935-36 will shortly be awarded by the Medical Research Council, and applications should be lodged with the Council not later than June 1, 1935. These Fellowships are provided from a fund with which the Medical Research Council has been entrusted by the Rockefeller Foundation. Fellowships are awarded by the Council, in accordance with the desire of the Foundation, to graduates who have had some training in research work in the primary sciences of medicine, or in clinical medicine or surgery, and are likely to profit by a period of work at a university or other chosen centre in the United States or on the Continent of Europe, before taking up positions for higher teaching or research in the British Isles. A Fellowship held in America will have the value of not less than $£ 350$ a year. Full particulars and forms of application are obtainable from the Secretary, Medical Research Council, 38 Old Queen Street, Westminster, S.W.1.

\section{Announcements}

His Majesty the King has conferred his patronage on the fifty-fourth annual meeting and conference of the Society of Chemical Industry to be held in Glasgow on July 1-6. Among the subjects to be discussed are the transport of food by road, rail and sea, problems of water supply, and chemical engineering in the Navy.

WE regret to announce the death, on April 27 at the age of seventy-three years, of Prof. H. B. Baker, F.R.S., lately professor of general chemistry in the Imperial College of Science and Technology.

Dr. George Sarton, editor of Isis, the quarterly organ of the History of Science Society and of the International Academy of the History of Science (Harvard Library, 185, Cambridge, Mass., U.S.A.), has been elected a corresponding member of the Academia de la Historia of Madrid.

ThE Ramsay Memorial Fellowships Trustees will consider at the end of June applications for a Ramsay Memorial Fellowship for chemical research, of the value of $£ 250$ a year. Particulars of the award can be obtained from the Secretary of the Ramsay Memorial Fellowships Trust, University College, London (Gower Street, W.C.1).

The Linacre Lecture at St. John's College, Cambridge, will be delivered by Mr. P. P. Laidlaw, pathologist to the Medical Research Council, National Institute for Medical Research, on Tuesday, May 7, at 5 p.m. in the new lecture-room of physiology. The title of the lecture will be "Epidemic Influenza: A Virus Disease".
A COURSE of eight lectures on pathological research in its relation to medicine is being given on Thursdays, commencing May 2, at the Institute of Pathology and Research, St. Mary's Hospital, W.2. The lecturers are Sir Almroth Wright, Prof. E. D. Adrian (electrical activity of the brain), Dr. I. N. Asheshov (bacteriophage), Dr. C. H. Andrewes (cancer), Dr. R. G. Canti (cultivation of living tissue), Sir Henry Dale (active substances of ergot), Mr. J. Henderson Smith (virus diseases of plants and animals) and Dr. J. Needham (chemical embryology). The lectures are open to members of the medical profession and medical students, without fee.

The seventh Natural Science Congress of the Dutch Indies will be held at Batavia on October 23-26. The agenda will include addresses by Prof. R. Remmelts and Dr. L. J. C. Van Es as well as meetings of sections. Further information can be obtained from the Secretariat, Koningsplein Z11, Batavia.

A SPECIAL exhibition of welding has been arranged at the Science Museum, South Kensington, and will remain on view until May 15. The exhibits include a wide range of machines used in welding by the oxy-acetylene, resistance, atomic hydrogen and arc processes, and a representative selection of examples of welded work. Demonstrations of the first three processes are being given daily at $11-1$ and 3-5, and films illustrative of welding are being shown every afternoon in the Lecture Theatre at 4 . The exhibition is supplementary to the symposium on welding on May 2-3 organised by the Iron and Steel Institute in co-operation with a number of other technical societies and institutions.

Applications are invited for the following appoint. ments, on or before the dates mentioned :-An assistant (II) for research in aero engines and accessories at the Royal Aircraft Establishment, South Farnborough, Hants-The Chief Superintendent (May 7). A laboratory research assistant in the Glamorgan County Mental Hospital, Bridgend-The Medical Superintendent (May 15). An assistant (Grade III) for abstracting scientific and technical papers in the Department of Scientific and Industrial Research-The Establishment Officer, 16 Old Queen Street, Westminster, S.W.1 (May 15). A head of the Mechanical Engineering Department, Central Polytechnic, Croydon-The Education Officer, Education Office, Katharine Street, Croydon (May 15). An inspector of agriculture in the Department of Agriculture and Forests, Sudan Government-The Controller, Sudan Government London Office, Wellington House, Buckingham Gate, London, S.W.1 (June 10). A lecturer in mathematics in Huddersfield Technical College-The Director of Education, Education Offices, Peel Street, Huddersfield. A principal of the Swansea Technical College-The Director of Fiducation, Swansea. An assistant for soil survey work at Harper Adams Agricultural College, Newport, Shropshire-The Principal. A lecturer in geography in Armstrong College, Newcastle-upon-Tyne-The Registrar. 